\title{
Implementasi Kebijakan Otonomi Khusus di Aceh \\ Implementation of Special Autonomy Policies In Aceh
}

\section{Debora Sanur L.}

Pusat Penelitian, Badan Keahlian DPR RI

email:debora_sanur@yahoo.com

\begin{tabular}{l} 
Riwayat Artikel \\
\hline Diterima: 31 Agustus 2019 \\
Direvisi: 9 Maret 2020 \\
Disetujui: 21 April 2020 \\
doi: $10.22212 /$ jp.v11i1.1580
\end{tabular}

do. $10.2212 /$ jp.v11i1.1580

\section{Abstract}

The granting of special autonomy or special authority by the central government to the Province of Aceh through the concept of asymmetric decentralization was aimed at embracing the province of Aceh to remain within the territory of the Republic of Indonesia and improve the welfare of the people of Aceh. Nevertheless, in its implementation, various problems were identified. This paper is intended to assess the implementation of Law No. 11 of 2006 concerning the Government of Aceh. The reason for this is because through the asymmetric decentralization policy, the central government has granted extensive concessions to the Province of Aceh by delegating various administrative and political authorities, managing local identity, to providing financial resources, in accordance with the LoGA. However, the challenge that comes with asymmetric decentralization policy is with the risk of failure in implementation if the central government and the provincial government of Aceh did not implement the mandate of the law optimally.

Keywords: Special Autonomy; Aceh Government; Asymmetric Decentralization; Policy Implementation.

\footnotetext{
Abstrak

Pemberian otonomi khusus atau kewenangan khusus oleh pemerintah pusat kepada Provinsi Aceh melalui konsep desentralisasi asimetris bertujuan untuk merangkul provinsi Aceh agar tetap berada dalam kesatuanNKRIdan meningkatkan kesejahteraan masyarakat Aceh. Meski demikian dalam implementasinya ditemukan berbagai permasalahan. Tulisan ini bertujuan untuk melihat bagaimana implementasi UndangUndang No. 11 Tahun 2006 tentang Pemerintahan Aceh dilaksanakan. Hal ini karena melalui kebijakan desentralisasi asimetris pemerintah pusat telah memberi konsesi-konsesi yang luas kepada Provinsi Aceh dengan melimpahkan berbagai kewenangan administrasi, politik, mengakomodasi identitas lokal, sampai memberikan sumber-sumber keuangan, sebagaimana yang diatur dalam UU PA. Akan tetapi yang menjadi tantangannya adalah, kebijakan desentralisasi asimetris itu bisa terancam gagal apabila dalam pelaksanaannya kinerja pemerintah pusat dan pemerintah provinsi Aceh tidak maksimal dalam melaksanakan amanat UU tersebut.

Kata kunci: Otonomi Khusus; Pemerintahan Aceh; Desentralisasi Asimetris; Implementasi Kebijakan.
} 


\section{Latar Belakang}

Amandemen UUD 1945 telah mengatur tentang desentralisasi dan satuan pemerintah daerah di Indonesia. Pengaturan tentang desentralisasi asimetris ditemukan dalam Pasal 18A ayat (1), Pasal 18B ayat (1) dan (2) UUD 1945. Dalam Pasal 18A ayat (1) diamanatkan bahwa "Hubungan wewenang antara pemerintah pusat dan pemerintahan daerah provinsi, kabupaten dan kota, diatur dengan undang-undang dengan memperhatikan kekhususan dan keragaman daerah". Lebih lanjut dalam Pasal 18B ayat (1) dan (2) diatur bahwa (1) Negara mengakui dan menghormati satuan-satuan pemerintahan daerah yang bersifat khusus atau bersifat istimewa yang diatur dalam undang-undang. (2) Negara mengakui dan menghormati kesatuankesatuan masyarakat hukum adat beserta hak-hak tradisionalnya sepanjang masih hidup dan sesuai dengan perkembangan masyarakat dan prinsip NKRI, yang diatur dalam UU.

Pada Provinsi Aceh, desentralisasi asimetris yang dilaksanakan lahir karena adanya kesepakatan perjanjian damai antara Gerakan Aceh Merdeka (GAM) dengan Pemerintah Republik Indonesia pada tanggal 15 Agustus 2005 atau yang lebih dikenal dengan $\mathrm{MoU}$ Helsinki. ${ }^{1}$ Perjanjian tersebut kemudian dituangkan dalam UU No. 11 tahun 2006 tentang Pemerintahan Aceh (UU PA). UU PA telah mengatur agar Provinsi Aceh memiliki kekhususan melalui konsep desentralisasi asimetris namun masih berada dalam kerangka sistem pemerintahan nasional Negara Kesatuan Republik Indonesia (NKRI). Dimana dalam pengaturannya dinyatakan

$1 \quad$ RI dan GAM berdamai di Helsinki, diakses tanggal 20 Agustus 2019, https:/liputan6.com/global/ $\mathrm{read} / 2294284 / 15-8-2005$-ri-dan-gam-berdamai-dihelsinki. bahwa pemberian Otonomi khusus kepada Aceh bukan hanya sekedar pemberian hak namun juga kewajiban konstitusional yang ditujukan bagi kesejahteraan masyarakat Aceh.

Sebelum UU No. 11 Tahun 2006 berlaku, ada beberapa regulasi yang mengatur tentang pemerintahan Provinsi Aceh. Pengaturan tersebut ialah UU No. 24 Tahun 1956, UU No. 44 Tahun 1999, UU No. 18 Tahun 2001. Dalam berbagai aturan tersebut nama Provinsi Aceh mengalami perubahan dari Daerah Istimewa Aceh (DI Aceh), Nanggroe Aceh Darussalam (NAD), dan Aceh. UU No. 24 Tahun 1956 tentang Pembentukan Daerah Otonom Propinsi Atjeh dan Perubahan Peraturan Propinsi Sumatera Utara telah mengatur bahwa Aceh dan Sumut merupakan daerah otonom yang terpisah dan berhak untuk mengatur dan mengurus rumah tangganya sendiri. $^{2}$

UU No. 44 Tahun 1999 tentang Penyelenggaraan Keistimewaan Propinsi Daerah Istimewa Aceh menyatakan bahwa keistimewaan daerah Aceh merupakan pengakuan bangsa Indonesia kepada daerah Aceh yang memiliki nilai-nilai hakiki masyarakat secara turun-temurun bahkan nilai-nilai tersebut telah dijadikan sebagai landasan spiritual, moral, dan kemanusiaan masyarakat Aceh. Dalam hal penyelenggaraan pemerintahan daerah bagi daerah yang bersifat istimewa, UU No. 44 Tahun 1999 membatasi pada 3 (tiga) sektor yang berhubungan dengan aspek kemasyarakatan, seperti: 1) penyelenggaraan kehidupan beragama, 2) penyelenggaraan kehidupan adat, dan 3) penyelenggaraan pendidikan. Pengaturan dibuat sektor yang berhubungan dengan masyarakat

2 Desentralisasi Asimetris Politik Aceh dan Papua, diakses tanggal 20 Agustus 2019, http://www. imparsial.org/publikasi/opini/desentralisasiasimetris-politik-aceh-dan-papua/. 
dilakukan oleh ulama dalam hal penetapan kebijakan daerah. Keistimewaan pada aspek kemasyarakatan secara umum diwujudkan dalam bentuk pelaksanaan Syariat Islam bagi pemeluknya. Adapun yang dimaksud dengan Syariat Islam ${ }^{3}$ adalah tuntutan ajaran Islam dalam semua aspek kehidupan.

Selanjutnya UU No. 18 Tahun 2001 tentang Otonomi Khusus Bagi Daerah Istimewa Aceh sebagai Provinsi NAD memuat pengaturan terkait perubahan penerapan asas penyelenggaraan pemerintahan di Indonesia dari asas sentralisasi menjadi desentralisasi. UU No. 18 Tahun 2001 pada prinsipnya mengatur kekhususan kewenangan pemerintahan di Provinsi Aceh yang berbeda dari kewenangan pemerintah daerah lainnya sebagaimana yang diatur dalam UU No. 22 Tahun 1999 tentang Pemerintahan Daerah dan UU No. 25 Tahun 1999 tentang Perimbangan Keuangan Antara Pemerintah Pusat dan Daerah ${ }^{4}$. Hal mendasar dari UU ini adalah: ${ }^{5}$

1. pemberian kesempatan yang lebih luas untuk mengatur dan mengurus rumah tangga sendiri termasuk sumber-sumber ekonomi, menggali dan memberdayakan sumber daya alam, dan sumber daya manusia;

2. menumbuh kembangkan prakarsa, kreativitas dan demokrasi, meningkatkan peran serta masyarakat, menggali dan mengimplementasikan tata bermasyarakat yang sesuai dengan nilai luhur kehidupan masyarakat Aceh;

3. memfungsikan secara optimal Dewan Perwakilan Daerah Provinsi NAD dalam memajukan penyelenggaraan pemerintahan di Provinsi NAD, dan

4. mengaplikasikan syariat Islam dalam kehidupan bermasyarakat.

3 Pasal 1 angka 10 UU No. 44 Tahun 1999.

4 Penjelasan Umum UU No. 18 Tahun 2001.

5 Penjelasan Umum UU No. 18 Tahun 2001.
Untuk melaksanakan berbagai kewenangan dalam rangka kekhususan, Pemerintah Pusat membuka peluang untuk meningkatkan penerimaan pemerintah Provinsi NAD termasuk kemungkinan tambahan penerimaan selain yang telah diatur dalam UU ini. UU ini menempatkan titik berat pelaksanaan otonomi khusus Provinsi NAD pada Kabupaten dan Kota atau nama lain secara proporsional. Kekhususan ini merupakan peluang Provinsi NAD untuk melakukan penyesuaian, a) struktur; b) susunan, c) pembentukan dan penamaan pemerintahan daerah di tingkat lebih bawah agar sesuai dengan jiwa dan semangat berbangsa dan bernegara namun tetap hidup dalam nilai-nilai luhur masyarakat Aceh ${ }^{6}$.

UU tersebut yang kemudian menjadi cikal bakal pemberian otonomi khusus kepada Provinsi Aceh untuk menjalankan rumah tangganya sendiri. Meski demikian, Undang-undang ini kemudian dicabut dengan berlakunya UU No. 11 Tahun 2006 tentang Pemerintahan Aceh yang berlaku hingga saat ini. Ketentuan dalam UU No. 11 Tahun 2006 mengenai perlunya norma, standar, prosedur, dan urusan yang bersifat strategis nasional menjadi kewenangan Pemerintah Pusat, bukan dimaksudkan untuk mengurangi kewenangan yang dimiliki Pemerintah Aceh dan Kabupaten/ Kota di Aceh. Melainkan merupakan bentuk pembinaan, fasilitasi, penetapan, dan pelaksanaan urusan pemerintahan yang dilakukan oleh pusat karena bersifat nasional. Dalam pengaturan ini perimbangan keuangan pusat dan daerah di Provinsi NAD, tercermin melalui pemberian kewenangan untuk pemanfaatan sumber pendanaan yang ada. Kerjasama pengelolaan sumber daya alam di wilayah NAD, diikuti dengan pengelolaan sumber

6 Penjelasan Umum UU No. 18 Tahun 2001. 
keuangan secara transparan dan akuntabel dalam rangka perencanaan, pelaksanaan, serta pengawasan. ${ }^{7}$ Sementara itu, dalam rangka mendukung pertumbuhan ekonomi masyarakat Aceh dilakukan pembangunan infrastruktur, penciptaan lapangan kerja, dan pengentasan kemiskinan dan kemajuan kualitas pendidikan. Dengan demikian, pemanfaatan dana otonomi khusus merupakan bagian yang tak terpisahkan dari pertumbuhan ekonomi nasional. ${ }^{8}$

\section{Rumusan Masalah}

Hadirnya berbagai pengaturan hingga diterapkannya kebijakan mengenai otonomi khusus bagi Aceh merupakan upaya pusat dalam menciptakan keadilan secara demokratis di Provinsi Aceh serta untuk mencapai tujuan otonomi daerah dalam kerangka NKRI. Meski demikian, dalam implementasi pelaksanaan UU PA masih ditemukan beberapa masalah yang harus menjadi perhatian Pemerintah. Tujuan pemberian otonomi khusus bagi Aceh pada pembangunan bidang infrastruktur, ekonomi rakyat, pengentasan kemiskinan, pendidikan, sosial, dan kesehatan belum sepenuhnya terwujud. Padahal, otonomi khusus bagi Provinsi Acehsudah berlangsung sejak tahun 2006 dan pemberian dana otonomi khusus telah diberikan sejak tahun 2008. Oleh sebab itu tulisan ini akan mengkaji tentang bagaimana implementasi kebijakan otonomi khusus di Provinsi Aceh?

\section{Desentralisasi Asimetris (Asymmetric Decentralization)}

Asas desentralisasi dikenal terbagi dalam 2 (dua) kategori, desentralisasi simetris (symmetric decentralization) dan desentralisasi asimetris (asymmetric decentralization) atau otonomi khusus.

7 Penjelasan Umum UU No. 18 Tahun 2001.

8 Penjelasan Umum UU No. 18 Tahun 2001.
Sebagaimana yang dikemukakan oleh Joachim Wehner, bahwa pemberian otonomi yang berbeda atas satu daerah dari beberapa daerah lainnya merupakan praktek penyelenggaraan pemerintahan yang cukup umum ditemui dalam pengaturan politik di banyak negara. Pengalaman ini berlangsung baik di dalam bentuk negara kesatuan yang didesentralisasikan, maupun dalam format pengaturan federatif. ${ }^{9}$

Secara prinsipil, berbagai bentuk penyebaran kekuasaan yang bercorak asimetris merupakan salah satu instrumen kebijakan yang dimaksudkan untuk mengatasi dua hal fundamental yang dihadapi suatu negara, yaitu pertama, persoalan bercorak politik, termasuk yang bersumber pada keunikan dan perbedaan budaya; dan kedua, persoalan yang bercorak teknokratis-manejerial, yakni keterbatasan kapasitas suatu daerah atau suatu wilayah dalam menjalankan fungsi dasar pemerintahan. ${ }^{10}$ Peter Harris dan Ben Reilly mengatakan bahwa melalui desentralisasi asimetris ini, wilayah-wilayah tertentu di dalam suatu negara diberikan kewenangan khusus yang tidak diberikan kepada wilayah-wilayah lain. ${ }^{11}$ Tujuan dari desentralisasi asimetris adalah untuk membuka ruang gerak implementasi dan kreativitas provinsi dalam pelaksanaan pemerintahan di luar ketentuan umum dan khusus yang berlaku nasional. Sedangkan secara konseptual, desentralisasi asimetris telah dipraktikkan di negara-negara federal maupun negara unitarian seperti di Wale,

9 Agung Djojosoekarto, dkk., Kebijakan Otonomi Khusus di Indonesia, Pembelajaran dari Kasus Aceh, Papua, Jakarta, dan Yogyakarta, (Jakarta: Kemitraan, 2008), 10.

10 Agung Djojosoekarto, dkk., Kebijakan Otonomi Khusus, 10.

11 Jacobus Perviddya Solossa, Otonomi Khusus Papua, Mengangkat Martabat Rakyat Papua di Dalam NKRI,(Jakarta :Pustaka Sinar Harapan,2006), 53. 
Irlandia, Spanyol dan Swedia. Walaupun pada mulanya pola ini tidak dimaksudkan untuk memberi kekhususan sebagaimana yang terjadi di Negara Republik Indonesia.

Menurut Maswadi Rauf, perbedaan desentralisasi simetris dan asimetris terletak pada tingkat kesesuaian (conformity) dan tingkat keumuman (commonality) dalam hubungan suatu pemerintahan (negara bagian/daerah), dengan sistem politik, maupun dengan pemerintah pusat dan daerah. ${ }^{12}$ Demikian pula pendapat Stefanus ${ }^{13}$ yang menyatakan bahwa konstitusi mengisyaratkan agar desentralisasi asimetris menekankan kekhususan, keistimewaan, keberagaman daerah, serta kesatuan-kesatuan masyarakat hukum adat dan hak-hak tradisional. Desentralisasi asimetris merupakan pelimpahan kewenangan khusus yang hanya diberikan kepada daerah-daerah tertentu. Desentralisasi asimetris juga merupakan strategi komprehensif pemerintah pusat guna merangkul kembali daerah yang hendak memisahkan diri dari NKRI. Melalui kebijakan desentralisasi asimetris keinginan maupun tuntutan atas identitas lokal suatu daerah dicoba diakomodirdalam suatu sistem pemerintahan lokal yang khas sehingga perlawanan terhadap pemerintah nasional dan keinginan untuk merdeka dapat dieliminasi. Meski demikian, pada tingkat implementasinya desentralisasi asimetris bisa terganggu apabila dalam daerah otonom masih terdapat kelompok yang tidak tulus menerima kebijakan tersebut. Desentralisasi asimetris itu juga bisa berjalan lamban apabila penyelenggara

12 M. Mas'ud Said, diakses tanggal 20 Agustus 2019, http://www.profmmasudsaid.com/newsdesentralisasi-asimetris.html, diakses tanggal 20 Agustus 2019.

13 Stefanus, K.Y. Pengembangan Desentralisasi Asimetris Dalam Negara Kesatuan Republik Indonesia. Makalah Seminar. 2009. pemerintahan yang menerimanya tidak kreatif, tidak inovatif, tidak responsif dan rendah kapasitas SDM aparaturnya dalam melaksanakannya. ${ }^{14}$

Dalam sistem pemerintahan negara Indonesia otonomi khusus baru dikenal pada era reformasi. Sebelumnya, di Indonesia hanya menggunakan istilah daerah khusus dan daerah istimewa. ${ }^{15}$ Daerah khusus merupakan daerah dengan struktur pemerintahan yang berbeda dengan daerah lain karena kedudukannya, sedangkan daerah istimewa adalah daerah yang memiliki struktur pemerintahan berbeda karena perbedaan atau keistimewaan berupa susunan asli masyarakat. Otonomi khusus secara resmi menjadi bagian dari sistem penyelenggaraan negara melalui Perubahan Kedua UUD NRI $1945 .{ }^{16}$

\section{Implementasi Kebijakan Otonomi Khusus di Aceh \\ Regulasi}

Setelah UU PA berlaku, ditemukan beberapa permasalahan dalam implementasinya. Dalam hal peraturan turunan dari UU No 11 Tahun 2006 tentang Pemerintahan Aceh, ditemukan bahwa masih terdapat 3 (tiga) Rancangan Peraturan Pemerintah (RPP) yang belum

14 Didik J. Rachbini. Ekonomi Politik dan teori Pilihan Publik. (Bogor: Ghalia Indonesia Anggota Ikapi, 2006), 20.

15 Pasal 18 UUDNRI 1945 sebelum Perubahan menyatakan "Pembagian daerah Indonesia atas daerah besar dan kecil, dengan bentuk susunan pemerintahannya ditetapkan dengan undangundang, dengan memandang dan mengingati dasar permusyawaratan dalam sistem pemerintahan negara, dan hak-hak asal usul dalam daerah-daerah yang bersifat istimewa."

16 Pasal 18B ayat (1) UUDNRI 1945 menyatakan bahwa "Negara mengakui dan menghormati satuansatuan pemerintahan daerah yang bersifat khusus atau bersifat istimewa yang diatur dengan undangundang." 
ditetapkan, yaitu; pertama, RPP tentang Standar, Norma, dan Prosedur Pembinaan dan Pengawasan PNS Provinsi Aceh dan Kabupaten/Kota. Kedua, RPP tentang Nama Aceh dan Gelar Pejabat Pemerintahan Aceh. Ketiga, RPP tentang Penyerahan Prasarana, Pendanaan, Personil, dan Dokumen Terkait dengan Pendidikan Madrasah Ibtidaiyah dan Madrasah Tsanawiyah. Demikian pula dalam tataran Qanun, terdapat 59 (lima puluh sembilan) Rancangan Qanun Aceh, yang harus diselesaikan sebagai implementasi UU PA dengan rincian 47 (80\%) judul Qanun telah berhasil disetujui bersama untuk disahkan/ ditetapkan dan diundangkan menjadi Qanun Aceh. Sementara itu, 12 (20\%) Rancangan Qanun belum berhasil disetujui bersama untuk disahkan/ditetapkan dan diundangkan menjadi Qanun Aceh.

Saat ini UU PA juga dihadapkan pada permasalahan Revisi UU No 11 Tahun 2006 tentang Pemerintahan Aceh sebagai akibat dari Putusan Mahkamah Konstitusi. Terdapat 2 (dua) Putusan MK atas pengujian terhadap UU tentang Pemerintahan Aceh, yang dikabulkan yaitu Putusan MK No. 35/PUU-VIII/2010 dan Putusan MK Perkara No. 51/PUU-XIV/2016. Putusan MK Perkara No. 35/PUU-VIII/2010, amar putusan yaitu membatalkan Pasal 256 UU Pemerintahan Aceh:

\section{Pasal 256}

Ketentuan yang mengatur calon perseorangan dalam Pemilihan Gubernur/Wakil Gubernur, bupati/wakil bupati, atau walikota/wakil walikota sebagaimana dimaksud dalam Pasal 67 ayat (1) huruf $d$, berlaku dan hanya dilaksanakan untuk pemilihan pertama kali sejak Undang-Undang ini diundangkan.

Sementara itu, Putusan MK Perkara No. 51/PUU-XIV/2016, amar putusan yaitu Pasal 67 ayat (2) huruf g UU Pemerintahan Aceh dinyatakan bertentangan dengan
UUD NRI Tahun 1945 secara bersyarat sepanjang tidak dimaknai dikecualikan bagi mantan terpidana yang secara terbuka dan jujur mengemukakan publik bahwa yang bersangkutan adalah mantan terpidana.

Pasal 67 ayat (2) huruf g

tidak pernah dijatuhi pidana penjara karena melakukan kejahatan yang diancamdengan hukuman penjara minimal 5 (lima) tahun berdasarkan putusan pengadilan yang telah mempunyai kekuatan hukum tetap, kecuali tindak pidana makar atau politik yang telah mendapat amnesti/rehabilitasi;

Selain Putusan MK tersebut, terdapat pula putusan MK pengujian terhadap Undang-Undang Nomor 7 Tahun 2017 tentang Pemilihan Umum (UU tentang Pemilu) yang terkait dengan UU PA, yaitu Putusan MK Perkara No. 61/PUU. XV/2017 dan Putusan MK Perkara No. 66/PUU-XV/2017. Hal ini karena dalam pembentukan UU tentang Pemilu tidak dilakukan konsultasi dan tidak mendapatkan pertimbangan dari DPRA sebagaimana seharusnya yang diatur dalam Pasal 8 ayat (2) UU PA. Permasalahan mengenai Pemilihan Umum ini terjadi karena undang-undang mengenai Pemilihan Kepala Daerah (Pilkada) dan undangundang mengenai Pemilihan Umum telah mengalami beberapa kali perubahan namun tidak diikuti oleh perubahan UU PA.

\section{Dana Otonomi Khusus}

Masalah berikutnya ialah terkait dengan dana otonomi khusus. Sesuai dengan ketentuan pada Pasal 183 ayat (2) UU No. 11 Tahun 2006 tentang Pemerintahan Aceh, dana otonomi khusus akan diberikan selama 20 (dua puluh) tahun dan dimulai sejak tahun 2008. Besaran dana otonomi khusus untuk tahun pertama (2008) hingga tahun kelima belas (2022) besarnya setara dengan 2 persen dari plafon Dana Alokasi 
Umum Nasional. Sedangkan untuk tahun ke enam belas (2023) hingga tahun kedua puluh (2028) besarnya setara dengan 1 persen dari plafon Dana Alokasi Umum Nasional. Secara kumulatif dana otonomi khusus hingga Tahun 2019 sudah diberikan sebesar 73,3 triliun. Meskipun demikian, Provinsi Aceh masih tergantung dengan keberadaan dana otonomi khusus dimana dana otonomi khusus berkontribusi lebih dari 50 persen dari Anggaran Pendapatan dan Belanja Daerah (APBD) dan dalam pelaksanaannya, masih terdapat permasalahan terkait alokasi dana antara Pemerintah Provinsi dan Kabupaten/Kota.

Perkembangan besaran dana otonomi khusus yang diberikan sejak tahun 2008 hingga 2019 dapat dilihat pada Gambar 1.

Secara umum Provinsi Aceh sangat tergantung pada keberadaan dana otonomi khusus ini. Sejak diberikan pada tahun 2018, angka kemiskinan di Provinsi Aceh cenderung menurun. Pada tahun 2008 angka kemiskinan di Provinsi Aceh mencapai 25,53 persen; sedangkan tahun 2017 angka kemiskinan sudah turun menjadi 16, 89 persen. Namun masih ada kesenjangan angka kemiskinan antara wilayah perkotaan dan pedesan di wilayah Provinsi Aceh. Pada tahun 2017, angka kemiskinan di wilayah perkotaan sebesar 11,11 persen; sedangkan angka kemiskinan di wilayah pedesaan masih sebesar 19,37 persen. ${ }^{17}$

\section{Kelembagaan}

Masalah berikutnya ialah terkait masalah kelembagaan. Lembaga Wali Nanggroe bukan merupakan lembaga politik dan lembaga pemerintahan di Aceh. Lembaga ini dipimpin oleh seorang Wali Nanggroe yang bersifat personal dan independen. Dalam Pasal 96 disebutkan bahwa Lembaga Wali Nanggroe merupakan kepemimpinan adat sebagai pemersatu masyarakat yang independen, berwibawa, dan berwenang membina dan mengawasi penyelenggaraan kehidupan lembagalembaga adat, adat istiadat, dan pemberian gelar/derajat dan upacara-upacara adat lainnya. Lembaga ini menerima anggaran yang berasal dari APBA. Saat ini Lembaga Wali Nanggroe dipimpin oleh Tengku Malik Mahmud Al-Haythar. Beliau memimpin Lembaga Wali Nanggroe sejak tahun 2012. Berdasarkan Qanun Aceh Nomor 9 Tahun 2013 tentang Perubahan Atas Qanun Aceh Nomor 8 Tahun 2012 tentang Lembaga Wali Nanggroe disebutkan bahwa susunan kelembagaan Wali Nanggroe terdiri dari:

17 Laporan Kinerja Dan Rekomendasi, Tim Pemantau DPR RI Mengenai Pelaksanaan Undang-Undang Nomor 11 Tahun 2006 Tentang Pemerintahan Aceh 2015 - 2019, DPR RI 2019, Belum Diterbitkan.

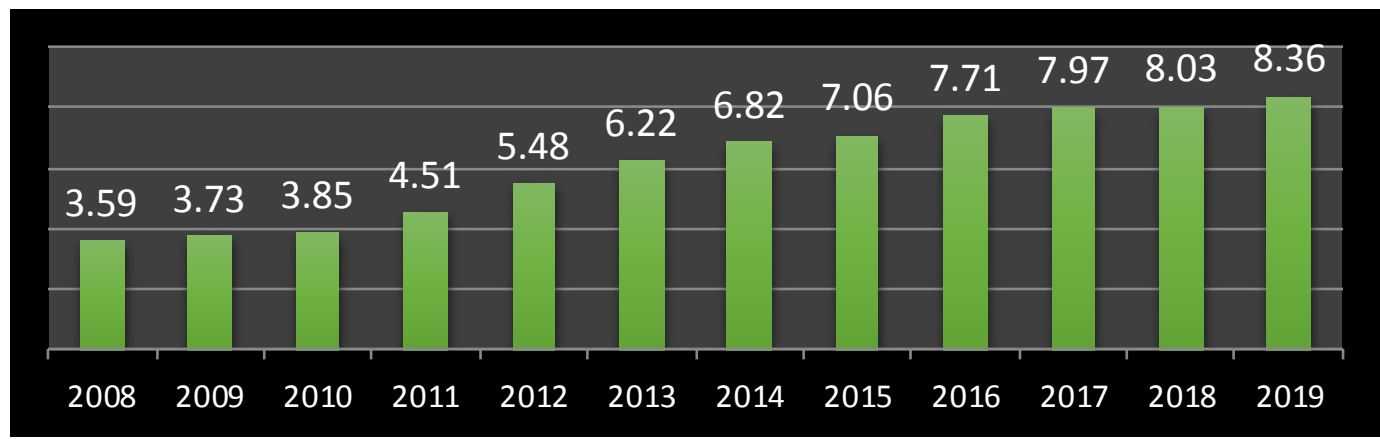

Sumber: Paparan Kementerian Keuangan pada FGD Evaluasi PelaksanaanDana Otonomi Khusus Acehdan Dana Keistimewaan DIY, 21 Maret 2019.

Gambar 1. Perkembangan Dana Otonomi khusus Provinsi Aceh 2008-2019 (Rp triiliun) 
a. Wali Nanggroe;

b. Waliyul'ahdi;

c. Majelis Tinggi; Majelis Tinggi terdiri dari Majelis Tuha Peut Wali Nanggroe; Majelis Fatwa; dan Majelis Tuha Lapan Wali Nanggroe.

d. Majelis Fungsional; Majelis Fungsional terdiri dari Majelis Ulama Naggroe Aceh (MUNA); Majelis Adat Aceh (MAA); Majelis Pendidikan Aceh (MPA); Majelis Ekonomi Aceh; Baitul Mal Aceh; Bentara; Majelis Hutan Aceh; Majelis Khazanah dan Kekayaan Aceh; Majelis Pertambangan dan Energi; Majelis Kesejahteraan Sosial dan Kesehatan; dan Majelis Perempuan.

e. Lembaga Struktural. Lembaga struktural yang dimaksud yaitu Keurokan Katibul Wali.

Menurut Kasubag Hukum Lembaga Wali Nanggroe, Syaiful, ${ }^{18}$ saat ini sedang dilakukan proses pembahasan perubahan Qanun Nomor 9 Tahun 2013, terkait perampingan lembaga pada Majelis Fungsional. Sebab, dengan lembaga yang sangat besar dinilai sangat sulit melakukan koordinasi, ditambah selama ini lembagalembaga tersebut juga belum terlihat dalam kerja Lembaga Wali Nanggroe.

Selanjutnya, UU PA juga mengatur pelaksanaan Syariat Islam dengan seluasluasnya di Provinsi Aceh. Untuk itu Pemerintah Aceh membentuk Dinas Syariat Islam (DSI) berdasarkan Qanun Aceh Nomor 13 tahun 2016 tentang Pembentukan dan Susunan Perangkat Daerah Aceh serta Peraturan Gubernur Nomor 131 Tahun 2016 tentang Kedudukan, Susunan Organisasi, Tugas, Fungsi dan Tata Kerja Dinas Syariat Islam dan Peraturan Gubernur No. 131 Tahun

18 Syaiful, Wawancara dilakukan pada tanggal 26 Juni 2019 pukul 14.00 di ruang kerja kantor Wali Nanggroe Aceh.
2016. DSI mempunyai tugas dan wewenang melaksanakan urusan pemerintah berkaitan dengan syariat Islam, yang meliputi bidang aqidah, syari'ah dan akhlak. Adapun kendala yang dihadapi dalam menjalankan kewenangannya. Namun, DSI tidak mampu terlalu jauh untuk menyentuh sasaran atau target yang diinginkan. Dan, sejak terjadinya perubahan struktur organisasi, di mana Wilayatul Hisbah (WH) sebagai unit pengawas dan penindak terhadap pelanggaran Syariat Islam tidak lagi berada di dalam struktur DSI, maka DSI tidak lagi mempunyai wewenang untuk mengawasi pelaksanaan Qanun secara langsung. Saat ini, wewenang tersebut ada di bawah Satuan Polisi Pamong Praja (Satpol PP) dan WH yang bekerja sama dengan instansi penegak hukum lainnya. DSI hanya menjadi lembaga pembuat regulasi, dan sebagai koordinator pelaksanaan syariat Islam.

Demikian pula dengan keberadaan Mahkamah Syar'iyah (MS) yang merupakan pengembangan dari Peradilan Agama. MS merupakan salah satu alat kelengkapan daerah dalam pelaksanaan otonomi khusus dan dalam Pasal 136 UU PA, menyebutkan bahwa "Penyediaan sarana dan prasarana serta penyelenggaraan kegiatan Mahkamah Syar'iyah dibiayai dari Anggaran Pendapatan dan Belanja Negara (APBN), APBA, dan Anggaran Pendapatan dan belanja Kabupaten/Kota (APBK)". Kendala yang dihadapi MS ialah keberadaan MS yang di bawah instansi vertikal, sehingga MS belum dapat menjalankan fungsinya secara maksimal. Sumber Daya Manusia (SDM) MS belum memadai bila dibanding dengan volume dan jenis perkara yang menjadi kewenangannya. Masih kurangnya SDM, Hakim dan Panitera Pengganti, baik kualitas maupun kuantitas sangat tidak memadainya sarana/prasarana, diantaranya belum adanya ruang tahanan yang representatif, 
dan belum adanya ruang tunggu serta ruang sidang anak, juga perangkat lainnya yang berhubungan dengan perkara anak.

Komisi Independen Pemilihan (KIP) sebagai penyelenggara Pemilu juga menemui kendala dalam pelaksanaan tugasnya. Kendala yang dihadapi oleh KIP diantaranya ialah masalah status KIP yang tidak tetap, sementara Panitia Pengawas Pemilihan (Panwaslih) bersifat tetap menurut UU Nomor 7 Tahun 2017 tentang Pemilihan Umum. Padahal, menurut UU PA dalam Pasal 60 ayat (1) disebutkan bahwa Panitia Pengawas Pemilihan Aceh bersifat ad hoc. Selain itu adanya perbedaan perlakuan antara partai politik (nasional) dengan partai politik lokal. Menurut anggota KIP Aceh, Ranisa, ${ }^{19}$ hal ini karena KIP hanya menerima dana dari APBN melalui Komisi Pemilihan Umum (KPU) Pusat terkait pelaksanaan pemilu yang melibatkan partai politik nasional. Namun, tidak ada alokasi dana untuk partai politik lokal. Akibatnya, KIP membagi alokasi anggaran yang diperuntukkan untuk parpol nasional kepada parpol lokal hingga menimbulkan protes dari parpol nasional karena anggaran yang diterima parpol nasional lebih kecil. Dilain pihak anggaran KIP dari Pemerintah Provinsi Aceh hanya pada saat pilkada (pemilihan gubernur/wakil gubernur atau bupati/wakil bupati dan walikota/wakil walikota, DPRA, atau DPRK), namun tidak pada pemilu yang bersifat nasional (pemilihan presiden/wakil presiden, DPR, atau DPD).

Demikian pula dengan kuota calon legislatif dari partai lokal yang muncul dalam Pemillu 2019. Persoalan tersebut terjadi karena menurut Pasal 244 UU Nomor 7 Tahun 2017 tentang Pemilihan Umum

19 Ranisa, Anggota KIP, dalam wawancara tanggal 26 Juni 2019 pukul 09.30 di ruang kerja kantor KIP Banda Aceh. disebutkan bahwa setiap partai hanya bisa mengajukan calon legislatif sebesar 100 persen dari jumlah kursi di parlemen. Namun, berdasarkan UU PA, disebutkan bahwa penyelenggaraan pemilihan umum di Aceh diselenggarakan berdasarkan Qanun Aceh. Qanun Nomor 3 Tahun 2008 dalam Pasal 17 menyatakan bahwa "Daftar bakal calon sebagaimana dimaksud dalam Pasal 15 memuat paling banyak 120 persen (seratus dua puluh perseratus) dari jumlah kursi pada setiap daerah pemilihan". Dalam kasus ini, Dewan Kehormatan Penyelenggara Pemilu (DKPP) menyatakan kebijakan KPU dan KIP Aceh yang mengakomodir kuota calon legislatif dari partai politik lokal di Aceh sebesar 120\% melanggar kode etik.

\section{Bidang Sosial}

Beberapa permasalahan lain juga ditemui dalam bidang sosial seperti kesehatan dan pendidikan. Menurut Dinas Kesehatan Provinsi Aceh, kesehatan dan pendidikan menjadi syarat mutlak dalam pengajuan usulan program dan kegiatan yang didanai dana otonomi khusus. Dalam hal ini dana otonomi khusus dari kabupaten/kota akan ditolak BAPPEDA jika tidak memasukkan kesehatan dan pendidikan.

Dalam Pasal 6 Qanun No. 4 Tahun 2010 mengatur bahwa Pemerintah Aceh wajib mengalokasikan anggaran minimal 10 persen (sepuluh persen) dari APBA untuk sektor kesehatan di luar gaji. Qanun No. 4 Tahun 2010 juga mewajibkan pemerintah Aceh dan pemerintah kabupaten/kota menyediakan dan memelihara fasilitas pelayanan kesehatan. ${ }^{20}$ Pada tataran empiris ada beberapa kendala yang dihadapi dalam pelaksanaan bidang kesehatan, diantaranya kekurangan tenaga kesehatan baik jumlah maupun jenisnya.

20 Pasal 8 ayat (1) juncto Pasal q3 ayat (1) Qanun No. 4 Tahun 2010. 
Berdasarkan Peraturan Menteri Kesehatan (Permenkes) No. 75 Tahun 2014 tentang Pusat Kesehatan Masyarakat (Puskesmas), ada 5 tenaga kesehatan dasar yang harus ada di setiap puskesmas, yaitu: 1) tenaga kesehatan masyarakat; 2) tenaga kesehatan lingkungan; 3) ahli teknologi laboratorium medik; 4) tenaga gizi; dan 5) tenaga kefarmasian. ${ }^{21}$ Selanjutnya pada tahun 2020, harus ada 9 (sembilan) jenis tenaga kesehatan di setiap puskesmas, yaitu: 1) dokter; 2) dokter gigi; 3) perawat; 4) bidan; 5) tenaga kesehatan masyarakat; 6) tenaga kesehatan lingkungan; 7) ahli teknologi laboratorium medik; 8) tenaga gizi; dan 9) tenaga kefarmasian. Namun pada akhir 2018, hanya 18,2 persen dari 251 (dua ratus lima puluh satu) Puskesmas di Aceh yang telah memiliki 5 (lima) jenis tenaga kesehatan dasar.

Masalah lainnya terkait SDM adalah distribusitenaga kesehatanyang tidak merata (maldistribution), yaitu adanya penumpukan tenaga kesehatan di perkotaan padahal penempatan tenaga kesehatan dimaksudkan untuk mendayagunakan kesehatan pada daerah yang dibutuhkan, terutama daerah terpencil, tertinggal, perbatasan, dan kepulauan, serta daerah bermasalah kesehatan. ${ }^{22}$ Penumpukan tenaga kesehatan di perkotaan disebabkan ada keengganan untuk ditempatkan di daerah terpencil/ tertinggal. Mereka menggunakan koneksi untuk dapat ditempatkan di perkotaan. Akibatnya, layanan kesehatan di daerahdaerah terpencil/tertinggal kekurangan tenaga kesehatan. Sebagai contoh, kekurangan SDM tenaga kesehatan terjadi di Subulussalam. Di Subulussalam ada 1 (satu) Rumah Sakit (RS) type C, 7 (tujuh) puskesmas, dan 82 (delapan puluh dua)

21 Pasal 16 ayat (3) Permenkes No. 75 Tahun 2014.

22 Penjelasan Pasal 23 ayat (1) UU No. 36 Tahun 2014 tentang Tenaga Kesehatan.
Pusat Kesehatan Desa (Puskesdes). Fasilitas RS di wilayah ini memadai, namun mereka kekurangan dokter anestesi maupun dokter spesialis lainnya. Sedangkan untuk puskesmas, mereka kekurangan 7 (tujuh) dokter umum dan 5 (lima) dokter gigi. Sedangkan di setiap Puskesdes hanya ada 1 (satu) bidan yang ditempakan melalui program bidan desa.

Dalam bidang pendidikan, pendidikan dayah merupakan salah satu kekhususan Aceh yang diakomodasi dalam Pasal 228 UU PA. Namun sejak terbentuknya UU PA, terjadi dualisme kewenangan antara Kementerian Agama dan Dinas Pendidikan Dayah. Sebelum dibentuknya UU No. 11 Tahun 2006, pembinaan dayah/ pesantren menjadi tugas dan fungsi dari Direktorat Jenderal Pendidikan Islam Kementerian Agama. Mengingat Dinas Pendidikan Dayah masuk dalam kelompok urusan Pemerintahan wajib lainnya yang bersifat keistimewaan dan kekhususan, dan bukan urusan pemerintahan bidang pendidikan maka sebelum Qanun No. 9 Tahun 2018 berlaku, Dinas Pendidikan Dayah tidak mendapatkan anggaran untuk penyelenggaraan pendidikan yang besarnya paling sedikit 20 persen dari APBA/APBK..$^{23}$ Akibatnya Dinas Pendidikan Dayah Aceh kekurangan dana karena setiap tahun hanya menerima dana di bawah 5 persen dari 20 persen anggaran penyelenggaraan Pendidikan, sementara dayah yang dibina cukup banyak. Dengan terbentuknya Qanun No. 9 Tahun 2018, pendidikan dayah mendapat alokasi dana paling kurang 30 persen dari alokasi dana pendidikan Aceh. Namun ketentuan tersebut belum dilaksanakan karena terkait dengan sistem penganggaran yang mulai berlaku pada tanggal 8 Januari 2019. Dengan demikian, diharapkan untuk tahun anggaran 2020,

23 Pasal 193 ayat (1) UU No. 11 Tahun 2006. 
pendidikan dayah sudah mendapatkan alokasi anggaran paling sedikit 30 persen dari alokasi anggaran bidang pendidikan pada APBA dan APBK.

\section{Bidang Pertanahan}

Pelaksanaan kewenangan khusus di bidang pertanahan yang diberikan kepada Pemerintah Aceh ini tetap harus memperhatikan UU No. 5 Tahun 1960 tentang Peraturan Dasar Pokok-Pokok Agraria (UU No. 5 Tahun 1960) dan UU No. 23 Tahun 2014 tentang Pemerintahan Daerah (UU No. 23 Tahun 2014).

UU No. 5 Tahun 1960 mengatur mengenai hak menguasai negara sebagaimana dimuat dalam Pasal 2 ayat (2) UU No. 5 Tahun 1960. Hak ini memberikan kewenangan kepada negara untuk:

a. Mengatur dan menyelenggarakan peruntukan, penggunaan, persedaiaan, dan pemeliharaan tanah;

b. Menentukan dan mengatur hubunganhubungan hukum antara orang-orang dengan tanah;

c. Menentukan dan mengatur hubunganhubungan hukum antara orang-orang dan perbuatan-perbuatan hukum mengenai tanah.

Undang-undang ini juga mengatur hubungan hukum tanah dengan orang, fungsi sosial dari tanah itu sendiri serta tanah sebagai perekat kesatuan bangsa Indonesia.

Pasal 2 UU No. 5 Tahun 1960 tersebut menegaskan bahwa hak menguasai negara atas tanah dalam pelaksanaannya dapat dikuasakan kepada daerah-daerah dan masyarakat-masayarakat hukum adat selama hal tersebut memang diperlukan dan tidak bertentangan dengan kepentingankepentingan nasional menurut ketentuanketentuan dalam peraturan pemerintah. Hak menguasai yang dimiliki oleh negara pelaksanaannya dapat dilimpahkan kepada daerah bila diperlukan dan tidak bertentangan dengan kepentingan nasional, yang akan diatur dengan peraturan pemerintah.

Adapun kedudukan UU No. 5 Tahun 1960 sehubungan dengan kewenangan otonomi khusus di bidang pertanahan yang diberikan kepada Pemerintah Aceh, yaitu segala ketentuan mengenai pertanahan yang memberikan kewenangan kepada Pemerintah Aceh melalui UU PA tetap mengacu pada UU No. 5 Tahun 1960 dan peraturan perundang-undangan lainnya mengenai pertanahan. Hal ini karena pertanahan tidak diatur secara teknis dalam UU PA sehingga implementasi atau pelaksanaannya tetap harus mengacu kepada UU No. 5 Tahun 1960 dan regulasi lainnya.

Menurut UU PA, Aceh diberikan kekhususan dalam pengelolaan sumber daya alam, termasuk bidang tanah. Hal tersebut menjadi salah satu urusan wajib yang diberikan oleh Pemerintah Pusat kepada Pemerintah Aceh sebagai daerah khusus. Pasal 16 UU PA menyebutkan bahwa sejumlah urusan wajib yang menjadi kewenangan Pemerintahan Aceh, di antaranya, pelayanan pertanahan skala Aceh atau lintas kabupaten/kota, sedangkan Pasal 17 UU PA menyebutkan salah satu urusan wajib pemerintah kabupaten/ kota adalah pelayanan pertanahan skala kabupaten/kota.

Oleh sebab itu, belum adanya Qanun tentang Pertanahan menimbulkan kekhawatiran bagi pemegang Hak Guna Usaha (HGU) dan Hak Guna Bangunan (HGB) terkait kepastian hukum tentang hak atas tanah yang dimilikinya bila ketentuan Pasal 213 dan Pasal 214 diimplementasikan. Berkaitan dengan peraturan perundangundangan ini, sebenarnya tidak terjadi tumpang tindih peraturan di bidang pertanahan dengan adanya UU PA karena 
yang diatur di dalam UU PA adalah khusus tentang pemberian HGU dan HGB sebagaimana diatur Pasal 213 dan Pasal 214 UU PA. Meski demikian, pemberian HBU dan HGB ini harus tetap sesuai dengan norma, standar, dan prosedur yang berlaku secara nasional, sehingga perlu dilakukan penyesuaian terhadap aturan teknis terkait pemberian HGU dan HGB yang berlaku selama ini khusus untuk Provinsi Aceh. ${ }^{24}$

Sama halnya dengan implementasi Pasal 213, Pasal 214, Pasal 215 UU PA. Dalam rencana pelaksanaanya perlu dilakukan diskusi/dengar pendapat dengan Pemerintah Provinsi Aceh agar mempunyai pemahaman dan persepsi yang sama tentang maksud dan tujuan yang diatur di dalam UU PA khususnya terkait pertanahan.

Pasal 213 menentukan bahwa Setiap warga negara Indonesia yang berada di Aceh memiliki hak atas tanah sesuai dengan peraturan perundang-undangan. Untuk itu, Pemerintah Aceh dan/atau pemerintah kabupaten/kota berwenang mengatur dan mengurus peruntukan, pemanfaatan dan hubungan hukum berkenaan dengan hak atas tanah dengan mengakui, menghormati, dan melindungi hak-hak yang telah ada termasuk hak-hak adat sesuai dengan norma, standar, dan prosedur yang berlaku secara nasional. Adapun Pasal 214 UU PA menentukan bahwa Pemerintah Aceh berwenang memberikan hak guna bangunan dan hak guna usaha bagi penanaman modal dalam negeri dan penanaman modal asing sesuai dengan norma, standar, dan prosedur yang berlaku. Ketentuan lebih lanjut mengenai tata cara pemberian hak ini diatur dengan Qanun Aceh.

Secara umum, kendala atau permasalahan yang terjadi dalam rangka

24 Laporan Kinerja Dan Rekomendasi, Tim Pemantau DPR RI Mengenai Pelaksanaan Undang-Undang Nomor 11 Tahun 2006 Tentang Pemerintahan Aceh 2015 - 2019, DPR RI 2019, Belum Diterbitkan. pelaksanaan atau implementasi UU PA terkait pertanahan adalah masih adanya perbedaan pemahaman dari Pemerintah Provinsi Aceh dalam memahami arti, maksud, dan tujuan juga pelaksanaan terhadap isi dari UU PA khususnya terkait pertanahan dan permasalahan pelaksanaan Pasal 253 UU PA. Dengan pertimbangan untuk melaksanakan ketentuan Pasal 253 UU PA, Presiden Joko Widodo pada tanggal 12 Februari 2015 telah menandatangani Perpres No. 23 Tahun 2015 tentang Pengalihan Kantor Wilayah Badan Pertanahan Nasional Aceh dan Kantor Pertanahan Kabupaten/Kota menjadi Badan Pertanahan Aceh dan Kantor Pertanahan Aceh Kabupaten/Kota. Perpres No. 23 Tahun 2015 tersebut menyebutkan bahwa dalam rangka melaksanakan pelayanan pertanahan di Aceh perlu dibentuk Badan Pertanahan Aceh yang merupakan perangkat daerah Aceh. Badan Pertanahan Aceh melaksanakan tugas dan fungsinya sesuai dengan ketentuan peraturan perundang-undangan..$^{25}$

Seiring dengan pendirian tersebut, melalui Perpres No. 23 Tahun 2015 Kantor Wilayah Badan Pertanahan Provinsi Aceh dialihkan menjadi Badan Pertanahan Aceh. Adapun ketentuan mengenai bentuk dan susunan organisasi, tugas, dan fungsi Badan Pertanahan Aceh akan diatur dengan Qanun Aceh. Perpres No. 23 Tahun 2015 ini menegaskan kepala Badan Pertanahan Aceh diangkat dan diberhentikan oleh Menteri Agraria dan Tata Ruang/Kepala Badan Pertanahan Nasional atas usul Gubernur Aceh. Senada dengan itu, dengan peraturan presiden ini, Kantor Pertanahan Kabupaten/ Kota di Aceh dialihkan menjadi Kantor Pertanahan Aceh Kabupaten/Kota. Kepala

25 Laporan Kinerja Dan Rekomendasi, Tim Pemantau DPR RI Mengenai Pelaksanaan Undang-Undang Nomor 11 Tahun 2006 Tentang Pemerintahan Aceh 2015 - 2019, DPR RI 2019, Belum Diterbitkan. 
Kantor Pertanahan Aceh Kabupaten/Kota diangkat dan diberhentikan oleh Menteri Agraria dan Tata Ruang/Kepala Badan Pertanahan Nasional atas usul Gubernur Aceh.

Namun, hingga saat ini belum ada implementasi Perpres No. 23 Tahun 2015. Implementasi Perpres tersebut belum bisa dilaksanakan karena peraturan pelaksanaan dan hal-hal yang dipersyaratkan di dalam Perpres belum tersedia dan belum dilaksanakan. Perpres ini belum dieksekusi secara maksimal oleh pemerintah pusat. ${ }^{26}$ Adapun permasalahan Perpres No. 23 Tahun 2015, yaitu pengalihan pegawai, anggaran, dokumen, dan lain-lain masih dipegang oleh Kantor Wilayah Badan Pertanahan Nasional Provinsi Aceh, belum diserahkan kepada Badan Pertanahan Aceh karena pengalihan ini baru terjadi secara hukum. Hal ini mengakibatkan ketidakpastian hukum pertanahan, seperti bentuk sertifikat, akta, dan penyelesaian konflik. Selain itu hal ini juga menimbulkan anomali ketidakseriusan pemerintah dalam melaksanakan UU PA dan MoU Helsinki.

Salah satu faktor terhambatnya implementasi Perpres No. 23 Tahun 2015 disebabkan oleh SDM yang dinilai belum terpenuhi, untuk menjalankan peraturan presiden tersebut. Dengan begitu, kementerian masih melihat kesiapan Pemerintah Aceh saat pengalihan itu dilaksanakan. ${ }^{27}$

\section{Evaluasi Kebijakan Otonomi Khusus Aceh}

Berdasarkan hal tersebut diatas, terdapat permasalahan yang menghambat

26 Wawancara dengan Kepala Dinas Pertanahan Kota Subulussalam, 11 Juli 2019.

27 Laporan Kinerja Dan Rekomendasi, Tim Pemantau DPR RI Mengenai Pelaksanaan Undang-Undang Nomor 11 Tahun 2006 Tentang Pemerintahan Aceh 2015 - 2019, DPR RI 2019, Belum Diterbitkan. implementasi UU PA secara penuh. Menurut Husni Jalil28, materi muatan dalam UU PA banyak yang tumpang tindih dengan baik Undang-Undang Nomor 23 Tahun 2014 tentang Pemerintah Daerah maupun dengan Peraturan Perundangundangan lainnya. Hal ini sejalan dengan temuan penelitian yang menyatakan bahwa masyarakat dan Pemerintah Aceh menilai dukungan dari Pemerintah Pusat yang terkesan masih setengah hati menjadi salah satu penyebab kurang efektifnya implementasi UU PA. ${ }^{29}$ Pelaksanaan UU PA belum sepenuhnya berjalan di Aceh. Banyak hal yang diamanatkan oleh undangundang tersebut belum direalisasi oleh pemerintah pusat. Beberapa kendala yang menyebabkan tidak implementasi UU PA adalah karena beberapa aturan teknis yang belum selesai dibuat oleh pemerintah pusat. Hingga saat ini, baru ada satu peraturan pemerintah dan peraturan presiden yang berlaku untuk mengimplementasikan UU PA, padahal banyak hal lain yang juga membutuhkan pengaturan.

Oleh sebab itu, pemerintah pusat perlu untuk mengevaluasi kembali kebijakan otonomi Khusus di Aceh berdasarkan prinsip-prinsip pemberian kewenangan khusus. Kewenangan tersebut juga harus disesuaikan dengan prinsip-prinsip pemberiankewenangankhusus atau otonomi yang seluas-luasnya kepada pemerintahan Aceh dilaksanakan sebagaimana yang

28 Husni Jalil, dari Fakultas Hukum Universitas Syiah Kuala, Laporan Hasil Pengumpulan DataDalam Rangka Penyusunan Naskah Akademik Dan Draf RUU Tentang Perubahan Atas Undang-Undang Nomor 11 Tahun 2006 Tentang Pemerintahan Acehtanggal 12 S/D 15Februari 2020.

29 Kurniawan. (2016). Pelaksanaan Kewenangan Khusus Pemerintahan Menurut UU Nomor 11 Tahun 2006 Tentang Pemerintahan Aceh (Suatu Penelitian Di Kabupaten Aceh Barat). Yustisia Jurnal Hukum. 95. 10.20961/yustisia.v95i0.2802. 
tercantum dalam Bab $\mathrm{V}$ tentang Urusan Pemerintahan UU PA ${ }^{30}$ sebagai berikut;

Pertama, penyelenggaraan kewenangan khusus atas otonomi yang seluas-luasnya dilaksanakan dengan memperhatikan aspek demokrasi, pengelolaan pemerintahan daerah yang baik (good local governance), keadilan, pemerataan, kesejahteraan, serta potensi dan keanekaragaman Aceh.

Kedua, pelaksanaan otonomi daerah yang seluas-luasnya didasarkan pada kewenangan khusus yang diberikan pemerintah pusat kepada pemerintahan Aceh dalam mengatur dan mengurus sendiri urusan pemerintahan dan kepentingan masyarakatnya.

Ketiga, pelaksanaan kewenangan khusus pemerintahan Aceh diletakkan pada satuan pemerintahan daerah provinsi. Pemerintahan kabupaten/kota dapat menerima penyerahan sebagian kewenangan khusus dari pemerintahan daerah provinsi.

Keempat, pelaksanaan kewenangan khusus pemerintahan Aceh harus sesuai dengan konstitusi negara dan peraturan perundangundangan yang berlaku, sehingga tetap terjamin hubungan yang serasi antara pemerintah pusat dan daerah serta antar daerah.

Kelima, pelaksanaan kewenangan khusus pemerintahan Aceh di bidang politik harus lebih meningkatkan kemampuan pemerintahan Aceh untuk menyelenggarakan pemerintahan daerah secara demokratis, transparan, akuntabel, professional, efisien, dan efektif.

Keenam, pelaksanaan kewenangan khusus pemerintahan Aceh di bidang ekonomi harus lebih meningkatkan kemampuan pemerintahan Aceh dalam memanfaatkan dan mengelola kekayaan alam daerah Aceh untuk sebesar-besarnya kemakmuran rakyat Aceh.

30 Pasal 11 sampai dengan Pasal 19 UU No. 11 Tahun 2006.
Ketujuh, pelaksanaan kewenangan khusus pemerintahan Aceh di bidang sosial budaya harus lebih meningkatkan kemampuan pemerintahan Aceh dalam memajukan pelaksanaan syariat Islam dan kesejahteraan masyarakat Aceh.

Kedelapan, pelaksanaan kewenangan khusus pemerintahan Aceh harus lebih meningkatkan peranan dan fungsi lembaga legislatif, badan eksekutif, partaipartai politik, dan lembaga-lembaga sosial kemasyarakatan lainnya di Aceh.

Selanjutnya untuk mengatasi permasalahan dalam implementasi UU PA, pemerintah pusat perlu konsisten dalam pemberian kewenangan terhadap Provinsi Aceh. Dalam hal ini pemerintah pusat harus senantiasa berpegang pada prinsip bahwa Aceh merupakan Provinsi yang bersifat istimewa dan diberi kewenangan khusus untuk mengatur dan mengurus sendiri urusan pemerintahan dan kepentingan masyarakat setempat sebagaimana dimaksud dalam Pasal 18. 18A, dan 18B UUD 1945, yaitu penyelenggaraan urusan pemerintahan dilakukan oleh Pemerintahan Aceh dan DPRA di Daerah Provinsi Aceh. Pemerintah pusat juga perlu untuk terus mendorong agar setiap lembaga yang ada di Aceh dapat bekerja secara optimal dalam melaksanakan otonomi khusus di Aceh. Lembaga tersebut diantaranya Komisi Independen Pemilihan (KIP) yang diberi wewenang untuk menyelenggarakan pemilihan Gubemur/Wakil Gubernur, Bupati/ Wakil Bupati, dan Walikota/Wakil Walikota. Partai Politik Lokal yang dibentuk untuk memperjuangkan kepentingan agama, masyarakat, bangsa dan negara.

Terkait masalah Pilkada dan Pemilu penting bagi pusat untuk memperhatikan kesesuaian tentang jumlah anggota KIP dan anggota Panwaslih yang disesuaikan dengan UU PA sebagai kekhususan yang 
telah diberikan kepada Aceh sehingga tidak tumpah tindih dengan UndangUndang Pemilu Nomor 7 Tahun 2017. Demikian pula dengan alokasi anggaran bagi KIP yang berasal dari dana Otonomi khusus, mengingat KIP merupakan salah satu lembaga kekhususan yang hanya ada di Aceh.

Demikian pula dengan perampingan lembaga pada Majelis Fungsional Wali Nanggroe. Sebab, lembaga yang besar dinilai menyulitkan internal mereka dalam melakukan koordinasi. Selain itu, peran lembaga-lembaga tersebut juga belum terlihat dalam kerja Lembaga Wali Nanggroe.

Sementara itu terkait dengan pemberian dana otonomi khusus, menurut Husni Jalil ${ }^{31}$ dana otonomi khusus Aceh perlu ditinjau kembali batas waktunya. Ia menyarankan agar Dana Otonomi khusus Provinsi Aceh tidak dibatasi waktunya. Pengaturan perlu memuat agar dalam pengelolaan dana otonomi khusus pusat perlu dilibatkan terutama dalam pemanfaatannya. Hal ini penting agar tidak terjadi penyimpangan dalam penggunaannya. Hal yang senada juga disampaikan oleh Djohermansyah Johan ${ }^{32}$ yang menyarankan agar pemberian dana Otonomi khusus bagi Aceh diberikan 1 (satu) putaran lagi, hingga perekonomian Provinsi Aceh dapat mandiri.

Berdasarkan masukan tersebut, pemerintah pusat perlu mempertimbangkan agar alokasi dana otonomi khusus diperpanjang. Terutama karena Aceh merupakan daerah yang pernah mengalami konflik dan juga memiliki beberapa lembaga

31 Laporan Hasil Pengumpulan Data Dalam Rangka Penyusunan Naskah Akademik Dan Draf RUU Tentang Perubahan Atas Undang-Undang Nomor 11 Tahun 2006 Tentang Pemerintahan Aceh tanggal 12 S/D 15Februari 2020.

32 Djohermansyah Johan, dalam FGD tentang rencana revisi UU PA yang dilaksanakan di PUU BK DPRRI khusus sebagai pelaksanaan UU PA dimana eksistensi lembaga tersebut akan sangat riskan jika dana Otonomi khusus tidak perpanjang. Keberadaan lembaga-lembaga khusus tersebut merupakan bagian penting dari resolusi konflik Aceh dan mengakar pada kultur Aceh. Eksistensi lembagalembaga tersebut sangat menentukan bagi keberlanjutan perdamaian Aceh. Selain itu, lembaga-lembaga tersebut juga tidak memiliki lembaga induk atau Kementerian di pusat sebagai Pembina. Dengan keberlanjutan alokasi dana otonomi khusus maka eksistensi lembaga tersebut dapat terjaga. ${ }^{33}$

Meski demikian, pusat juga dapat mendorong Provinsi Aceh agar membuat pengaturan tentang hak dan kewenangan Pemerintah Aceh dalam pengelolaan sumber daya alam (SDA) di Aceh yang meliputi perencanaan, pelaksanaan, pemanfaatan dan pengawasan kegiatan usaha dengan menerapkan prinsip transparansi dan pembangunan berkelanjutan. Pelaksanaannya juga dilakukan dengan memberdayakan masyarakat secara maksimal dan mengikutsertakan SDM setempat dan sumber daya lainnya yang ada di Aceh. Sama hal nya dengan sektor perdagangan dan investasi, pemerintah Pusat perlu mendorong pemerintah Aceh/ Kabupaten/Kota untuk mengoptimalkan potensi masyarakat dalam melakukan perdagangan dan investasi secara internal dan internasional sesuai dengan peraturan perundang-undangan.

\section{Kesimpulan}

Pemberian otonomi khusus melalui sistem desentralisasi asimetris kepada

33 Laporan Kinerja Dan Rekomendasi, Tim Pemantau DPR RI Mengenai Pelaksanaan Undang-Undang Nomor 11 Tahun 2006 Tentang Pemerintahan Aceh 2015 - 2019, DPR RI 2019, Belum Diterbitkan. 
Provinsi Aceh merupakan pilihan politis masyarakat Aceh untuk menerima kesediaan bekerjasama dalam bingkai NKRI. Hal ini dilakukan demi mewujudkan keadilan rakyat Aceh yang terabaikan pada masa lalu atas perilaku elit pemerintah pusat. Meski demikian kekurangan dari penerapan otonomi khusus yang masih terlihat diantaranya dalah tidak dielaborasinya pengaturan agar sesuai dengan kebutuhan untuk mendemokratisasi dan merestrukturisasi politik lokal di Aceh. Saat ini masyarakat Aceh tentu mengharapkan perkembangan-perkembangan positif dari kebijakan Pusat melalui kebijakan otonomi khususnya.

Otonomi melalui desentralisasi asimetris di Aceh telah memberi wewenang kepada provinsi tersebut untuk mengembangkan model pembangunan berbeda dan model demokratisasi yang unik berbasis pada kebudayaan masyarakatnya yang mewariskan nilai-niai agama dan adat yang kuat. Otonomi ini telah memberikan kekhususan tertentu bagi Aceh sehingga ruang gerak implementasi dan kreativitas sangat tergantung pada kemampuan provinsi dan kabupaten/kota. Ketidakseragaman pada beberapa hal, baik dalam sistem pemerintahan, kebijakan dan pembanguan memang memiliki tantangan tersendiri. Kearifan lokal menjadi hal yang lebih memainkan peranan bagi kebaikan dan kesejahteraan masyarakat. Oleh sebab itu, pengaturan khusus bagi keistimewaan Aceh dalam melaksanakan penyelenggaraan kehidupan beragama, kehidupan beradat, penyelenggaraan pendidikan, serta peran ulama dalam penetapan kebijakan daerah dan pemberdayaan perekonomian, merupakan kekayaan dinamika politik pemerintahan di NKRI yang patur dijaga dan dirawat bersama.
Secara umum selama ini pemerintahan di Provinsi Aceh telah dilaksanakan sesuai dengan ketentuan yang dimuat dalam UU PA. Meskipun demikian, beberapa kendala dalamimplementasipembagian kewenangan antara Pemerintah Pusat, Pemerintah Provinsi, dan Pemerintah Kabupaten/Kota perlu diatasi oleh pemerintah pusat dan Aceh. Implementasi dari UU No 11 Tahun 2006 tentang Pemerintahan Aceh yang menandai mulai berlakunya otonomi khusus bagi Provinsi Aceh belum seluruhnya dapat terlaksana dengan baik. Masih terdapat permasalahan, baik dalam bidang hukum, politik dan pemerintahan, serta bidang sosial.

Pemerintah Pusat dinilai belum konsisten dalam melaksanakan seluruh ketentuan yang ada dalam UU PA. UU PA juga dinilai mengandung multitafsir, sehingga untuk implementasinya tergantung bagaimana masing-masing pihak dalam menerjemahkannya. Dengan demikian pemerintah pusat perlu merevisi pengaturan bagi Provinsi Aceh. Sementara itu bagi Pemerintah Kabupaten/Kota Aceh kendala tersebut antara lain belum adanya Qanun yang mengatur kewenangan tentang kewenangan provinsi dan kabupaten/kota, yang mengakibatkan terjadi tumpang tindih kewenangan antara pemerintah provinsi dan kabupaten/kota.

Dalam bidang politik, kendala dalam implementasi pelaksanaan pemerintahan di Aceh, terdapat beberapa kendala dalam implementasi pembagian kewenangan antara pemerintah, pemerintah provinsi dan pemerintah kabupaten/kota juga perlu untuk diatasi. Salah satunya ialah bahwa Qanun yang mengatur tentang kewenangan Provinsi dan Kabupaten/Kota belum ada, sehingga mengakibatkan terjadi tumpah tindih kewenangan antara pemerintah provinsi dan kabupaten/kota. 
Kendala berikutnya, dalam bidang ekonomi, secara umum Provinsi Aceh sangat tergantung pada keberadaan dana otonomi khusus ini. Sejak pertama kali diberikan, dana otonomi khusus memberikan porsi signifikan terhadap APBD dengan persentase antara 38-59 persen. Sedangkan, peruntukkan dana otonomi khusus masih kurang produktif sehingga tidak mampu meningkatkan porsi PAD terhadap APBD. Selain itu, adanya kesenjangan antar daerah akibat dari perbedaan SDA, pendapatan asli daerah masih sangat rendah; sehingga hampir semua daerah baik provinsi maupun kabupaten/kota, masih sangat tergantung pada dana pemerintah baik dana otonomi khusus, perimbangan, DAU dan DAK.

Dalam bidang sosial, pada tataran empiris ada beberapa kendala yang dihadapi dalam pelaksanaan bidang kesehatan, diantaranya kekurangan tenaga kesehatan, baik jumlah maupun jenisnya. Seperti distribusi SDM tenaga kesehatan yang tidak merata (maldistribution) karena terjadi penumpukan tenaga kesehatan di perkotaan padahal penempatan tenaga kesehatan dimaksudkan untuk bekerja pada daerah yang membutuhkan, terutama daerah terpencil, tertinggal, perbatasan, dan kepulauan, serta daerah bermasalah kesehatan

Demikian pula dengan keterbatasan tenaga pendidik yang menyebabkan banyak pemilik dayah meminta Dinas Pendidikan Dayah untuk mengirim tenaga pendidik. Pada tahun 2017 Dinas Pendidikan Dayah telah merekrut 30 tenaga pendidik dengan status kontrak untuk ditempatkan di dayahdayah, khususnya yang ada daerah terpencil. Namun penempatan tenaga pendidik oleh Dinas Pendidikan Dayah akhirnya menimbulkan masalah karena terjadi kesenjangan besaran gaji yang diterima, karena gaji pendidik yang dikontrak Dinas
Pendidikan Dayah jumlahnya lebih tinggi jika dibandingkan gaji pendidik yang direkrut yayasan/pemilik dayah sehingga menimbulkan kecemburuan.

Dalam bidang pertanahan, hal yang paling penting saat ini dilakukan oleh Pemerintah Aceh adalah meningkatkan sinergitas antara Dinas Pertanahan serta Menteri Agraria dan Tata Ruang/Kepala Badan Pertanahan Nasional. Terutama karena Kanwil Badan Pertanahan Provinsi Aceh hingga saat ini masih berada di bawah Kementerian Agraria dan Tata Ruang/Badan Pertanahan Nasional yang ada di pemerintah pusat. Oleh karena itu, Pemerintah Aceh perlu untuk segera menyiapkan SDM di Aceh. Salah satu caranya dengan melaksanakan program menyekolahkan putra putri Aceh di Sekolah Tinggi Pertanahan Nasional melalui kerja sama (MoU) dengan Sekolah Tinggi Pertanahan Nasional.

Berdasarkan hal yang telah disebut di atas, maka permasalahan yang dihadapi oleh Pemerintah Aceh dalam pelaksanaan UU PA harus menjadi perhatian Pemerintah, mengingat masa berlaku otonomi khusus bagi Provinsi Aceh sudah berlangsung sejak 2006, dan pemberian dana otonomi khusus sudah diberikan sejak 2008, namun tujuan pemberian otonomi khusus bagi aceh pada pembagunan bidang infrastruktur, ekonomi rakyat, pengentasan kemiskinan, pendidikan, sosial, dan kesehatan belum sepenuhnya terwujud.

Pemerintah pusat harus membuat pengaturan yang jelas mulai dari penyusunan program, pelaksanaan, hingga pengawasan terhadap setiap kegiatan yang akan didanai oleh anggaran otonomi khusus. Kegiatan tersebut harus merupakan program dan kegiatan pembangunan yang strategis, mempunyai daya dorong yang kuat, dan berpengaruh signifikan terhadap 
pencapaian kesejahteraan masyarakat Aceh agar menjadi lebih baik, nyata, dan adil secara menyeluruh. Selain itu, penyusunan program juga harus memenuhi kriteria pemilihan program yang melibatkan masyarakat agar sesuai dengan kebutuhan masyarakat. Hal yang ditingkatkan ialah pelaksanaan Musyawarah Rencana Pembangunan (Musrenbang). Musrenbang merupakan salah satu mekanisme terkait perencanaan program kegiatan yang telah disusun dan diusulkan oleh Pemerintah Aceh dan Pemerintah Kabupaten/Kota.

\section{DAFTAR PUSTAKA}

Agustino, Leo. Sisi Gelap Otonomi Daerah. Bandung: Widya Padjadjaran. 2011.

Agung Djojosoekarto, dkk., Kebijakan Otonomi Khusus di Indonesia, Pembelajaran dari Kasus Aceh, Papua, Jakarta, dan Yogyakarta, Jakarta: Kemitraan, 2008.

Darmansjah Djumala, Soft Power Untuk Aceh: Resolusi Konflik dan Politik Desentralisasi, Jakarta: Gramedia.2013.

Desentralisasi Aceh, diakses tanggal 20 Agustus 2019.https://aceh.tribunnews. com/2015/03/03/desentralisasi-aceh.

Desentralisasi Asimetris Politik Aceh dan Papua, diakses tanggal 20 Agustus 2019 http://www.imparsial.org/publikasi/ opini/desentralisasi-asimetris-politikaceh-dan-papua/.

Didik J. Rachbini. Ekonomi Politik dan teori Pilihan Publik. Bogor : Ghalia Indonesia Anggota Ikapi, 2006.

Djohermansyah Djohan, Desentralisasi Asimetris Ala Aceh, diakses 20 Agustus 2019. https://www.academia.edu/3879561/ Desentralisasi_Asimetris_Ala_Aceh_ Djohermansyah_Djohan1_Pendahuluan.

Djohermansyah Johan, dalam FGD tentang rencana revisi UU PA yang dilaksanakan di PUU BK DPRRI, tanggal 6 Februari 2020.

Effendi, Sofyan. Reformasi Tata Kepemerintahan: Menyiapakan Aparatur Negara Untuk mendukung Demokratisasi Politik Dan Ekonomi Terbuka, Yogyakarta, Gadjah Mada University Press, 2010.

Huda, Ni'matul. Desentralisasi Asimetris Dalam NKRI Kajian Terhadap Daerah Istimewa, Daerah Khusus dan Otonomi Khusus. Bandung: Nusa Media, 2014.

Husin,Taqwaddin.Kapita Selekta Hukum Adat Aceh dan Qanun Wali Nanggroe, Banda Aceh: Banda Publishing, 2013.

Jacobus Perviddya Solossa, Otonomi Khusus Papua, Mengangkat Martabat Rakyat Papua di Dalam NKRI, Jakarta: Pustaka Sinar Harapan, 2006.

Kurniadi, B.D. 2012. Desentralisasi Asimetris di Indonesia. Seminar di LAN Jatinangor tanggal 26 November 2012. diakses tanggal 20 Agustus 2019 http://bdardias. staff.ugm.ac.id/wp-,.

M. Mas'ud Said, http://www.profmmasudsaid. $\mathrm{com} /$ news-desentralisasi-asimetris.html, diakses tanggal 20 Agustus 2019.

Rachbini, Didik J. Ekonomi Politik dan teori Pilihan Publik. Bogor: Ghalia Indonesia. 2006.

Ranisa, Anggota KIP, dalam wawancara tanggal 26 Juni 2019 pukul 09.30 di ruang kerja kantor KIP Banda Aceh.

Rasyidin. El. all. Desentralisasi Aceh Pasca Reformasi dan MoU Helsinki. Lhokseumawe: Unimal Press, 2015. 
RI dan GAM berdamai di Helsinki, diakses tanggal 20 Agustus 2019, https:// liputan6.com/global/read/2294284/15 8-2005-ri-dan-gam-berdamai-dihelsinki

4 tahun Pembagunan Aceh 2016, diakses 20 Agustus 2019. https://www1-media. acehprov.go.id/uploads/4_Thn Pembangunan_Aceh2016.pdf.

Laporan Kinerja Dan Rekomendasi, Tim Pemantau DPR RI Mengenai Pelaksanaan Undang-Undang Nomor 11 Tahun 2006 Tentang Pemerintahan Aceh 2015 - 2019, DPR RI 2019, Belum Diterbitkan.
Laporan Hasil Pengumpulan Data Dalam Rangka Penyusunan Naskah Akademik Dan Draf RUU Tentang Perubahan Atas Undang-Undang Nomor 11 Tahun 2006 Tentang Pemerintahan Aceh tanggal 12 S/D 15 Februari 2020.

Stefanus, K.Y. Pengembangan Desentralisasi Asimetris dalam Negara Kesatuan Republik Indonesia. Makalah Seminar.2009.

Syaiful, Wawancara dilakukan pada tanggal 26 Juni 2019 pukul 14.00 di ruang kerja kantor Wali Nanggroe Aceh.

Wawancara dengan Kepala Dinas Pertanahan Kota Subulussalam, 11 Juli 2019. 